\title{
The price of monotheism: some new observations on a current debate about late antiquity
}

\author{
Christoph Markschies
}

\section{RECENT DEBATE AND THE SILENCE OF HISTORIANS}

My title refers to Die Mosaische Unterscheidung oder der Preis des Monotheismus, the most prominent of Jan Assmann's publications, which have been at the centre of a debate about monotheism among contemporary theologians. ${ }^{\mathrm{I}}$ Assmann proposed a structural division between primary and secondary forms of religion which broadly conforms to the divide between polytheism and monotheism. The decisive factor in the emergence of secondary religious forms was not the decision to honour one rather than many gods, but to distinguish true from false doctrine. The choice of truth necessarily entailed the rejection of falsehood; thus the secondary religion was exclusive, not inclusive, and intolerant of error and religious deviation. The price for the identification and pursuit of religious truth was paid in hostility to and the repression of false gods, heresy and religious ideas that deviated from the true religion. Violence and hatred were therefore inevitable partners of secondary, monotheistic, religion. It is likely that widespread discussions of Assmann's thesis will continue, not without inevitable repetition of the ensuing arguments. This paper does not intend to side with Assmann's critics and praise monotheism for its integrative and peaceful characteristics, nor will it defend his views with new or old arguments. Rather, my reflections proceed from the comment recently made by a historian: 'the screaming muteness of the historians and scholars of the social sciences'. ${ }^{2}$

As an introduction I begin by asking a question that makes the historical and social dimension of the problem immediately apparent: if this is a discussion about monotheism, whose views are the subject of the debate? Or,

I Assmann (2003); cf. also Assmann (1999) and (2000), 62-80. This paper was prepared for the Religionswissenschaftliche Sozietät in the Forschungsstätte der Evangelischen Studiengemeinschaft e.V. (FEST) on I9 January 2004. Only the footnotes have been slightly augmented. I would like to thank Andreas Heiser for his assistance with the completion of the manuscript.

2 Weichlein (2003). 
to put it more clearly, who actually is a protagonist of the monotheism and the history of ideas that Jan Assmann has reconstructed, thereby initiating this heated discussion? What meaning does the concept of 'monotheism' have when it is considered on the level of 'religion as practised'? The collection of essays Religion und kulturelles Gedächtnis, edited by Assmann, contains a number of relevant critical statements. The remarks of Klaus Koch, Egyptologist and expert in the area of Old Testament studies, on the 'multifarious overlapping of poly- and monotheism' also seem to focus on the question I have raised, that is the question of religion as practised in concrete historical situations and social contexts. But he is also concerned with intellectual history, or the history of ideas, which he assigns to political, economical and social factors, and it comes as something of a surprise against this background when he suggests that Assmann's pursuit of a history of ideas is founded on thin air, in his words: 'Ideengeschichte gleichsam ohne Bodenhaftung. ${ }^{3}$ However, he himself is not far removed from this spectre, which looms over all recent historians and sociologists.

Of course Assmann is right first to reconstruct monotheism as a theoretical concept. But who would seriously consider that history is guided by ideas which are theoretical constructs in the first instance and are only represented in reality by the activities of a minority? His position takes for granted that this is 'no argument against the thesis of a Mosaic distinction, which finds no support in the history of religion in the sense that a strict monotheism existed neither in ancient Israel nor in early Judaism'; it takes for granted that very few advocates of this 'intellectual point of view' suffice to impose it; and it takes for granted that a few 'monotheistic elements' in polytheistic or syncretistic practice fulfil the requirements. ${ }^{4}$ But it must remain the privilege of the historian to ask why such ideas that stem from minorities become generally established, and why this was especially the case with pressure groups who were without political power. Furthermore, and not least, the historian must ask in what form these ideas, albeit generally in a moderated form, were concretely established.

THE CONCEPT OF MONOTHEISM IN THE RECENT

DEBATE IN GERMANY

In order not to assume the seemingly positivistic superior position of the historian of religion and pursue the question in total hermeneutic naïvety,

3 Koch (1999), reprinted in Assmann (2000), 234.

4 Assmann (2003), 5I clarifies his thesis in this way. 
it is, of course, necessary that I clarify a few points beforehand. With my introductory question of what is monotheism I am in fact searching for the monotheists. But what actually is monotheism? What concepts of monotheism have been assumed in the recent debate? Odo Marquard, in his somewhat mischievous and not totally serious pamphlet Lob des Polytheismus, linked monotheism with 'monomyth', 5 and formulated his wellknown working hypothesis: 'the polymyth is digestible, the monomyth detrimental'. ${ }^{6}$ The polymyth is fitted out with all kinds of notions which imply positive meanings. For example, leaving aside the culinary metaphor of 'digestibility', polymyth is also denoted as the more democratic form by reference to the key concept of 'division of power', ${ }^{7}$ since it allows man to develop his individuality freely. The classical form of polymyth was polytheism, because many different fables were related within it, ${ }^{8}$ while monotheism is the classical murderer of both polytheism and polymyth.

Comparably, Jan Assmann regards the decisive factor in monotheism not to be 'the differentiation between the one God and many gods...', but the distinction between 'the true God and the false gods', the socalled Mosaic distinction. ${ }^{9}$ In his latest book this is explicitly linked with the 'Parmenidean distinction' between true and false knowledge. Assmann explains that both the followers of monotheism and those of Parmenides must be structurally intolerant towards a false god or false knowledge. ${ }^{10}$ The 'enforcement of thought' in the Parmenidean distinction corresponds with the enforcing of belief in the Mosaic distinction, as Assmann put it in agreement with Werner Jaeger. ${ }^{\text {II }}$ It becomes clear from this comparison that here, in the first place, strict theoretical consistency is involved.

Of course, the political vocabulary of enforcement and tolerance which dominates Marquard's and Assmann's terminology suggests swift conclusions about how theory may be put into practice in the religion and philosophy of everyday life. In another paper I somewhat impertinently ascribed the use of this political vocabulary in the context of polytheism and monotheism to a 'concerned old European democratic view', which

5 Marquard (200ob), first published in 198I. Klaus Koch asserts rather disparagingly that the text gave the impression that the author was slightly inebriated whilst writing it.

6 Marquard (200ob), $98 . \quad 7$ Marquard (200ob), 98.

8 Marquard reduces religion as well as myth to this simple formula: Marquard (200ob), 93 and roo.

9 Assmann (2003), I2; Assmann (1998), 250. The first to advocate the Mosaic distinction, however, was not Moses, but the Egyptian pharaoh Akhenaten, who formed the basis of his 'theoclasm' in opposition to traditional Egyptian pantheism.

Io Assmann (2003), 23 and 26. II Assmann (2003), 24, in agreement with Jaeger (1934) I, 237. 
might be expected from the Giessen philosopher and the Heidelberg historian of religion. Naturally, at the time I did not seek to deny that there are always new grounds for expressing this concerned democratic view, and that it is perhaps not detrimental that such a perspective does play a role within historical research. ${ }^{12}$ The consequences of the chosen imagery come as no surprise. The fact that the 'monotheistically inspired writings of the Bible' represented the establishment of the worship of Yahwe, the one God, 'as violent, even as a direct result of a series of massacres' is a matter which is concerned with 'the cultural semantics and not the history of events', as Assmann himself proclaims. ${ }^{13}$ It is another question, however, whether one can describe these passages of the Old Testament as the 'anticipation of Auschwitz.'. 4

Against this theoretical background of a current debate I would now like to ask if one can really speak of 'monomyth' and of a definite distinction between the true God and false gods in the different forms of monotheism that are actually believed in - Hebrew, pagan and Christian. Can one really say that in piety as practised 'translatability is blocked's by the 'hermeneutics of difference' which were characteristic of the primary religions that existed before the 'monotheistic transformation', as formulated by Assmann? When Assmann claims that 'the religions always had a mutual basis. Therefore, they could function as a medium of intercultural translatability', were the features that characterised pre-monotheistic religions brutally destroyed ${ }^{16} \mathrm{Or}$, to put it in a different way, can we observe in these ancient forms of monotheistic piety what Odo Marquard sees as their inevitable implication, that is, the 'liquidation' of polymyth and polytheism?

I want to note explicitly that I do not want simply to join the mass of Assmann's critics, because in Assmann's most recent publication one can naturally also read that, as a matter of course, Christianity insisted on the 'universalisation of the Mosaic distinction', which 'no longer applies only for the Jews, but for all mankind'. ${ }^{17}$ Furthermore, one can find a memorable analysis which already observed this universalisation in Hellenistic Judaism. ${ }^{{ }^{8}}$ I essentially want to query once again the efficiency of the category of 'monotheism' as well as the duality of 'monotheism' and 'polytheism' as ways of comprehending the social and religious history of antiquity. I would call into question the efficiency of conceptual forms

\footnotetext{
I2 Markschies (2006). I3 Assmann (2004a), 37.

${ }^{14}$ Assmann (2000), 72. The passages referred to are Deut. 28. Is Assmann (2003), 38.

I6 Assmann (2003), I9. I7 Assmann (2003), 30.

I8 Assmann (2003), 44-7 (on Wisd. of Sol. I4:23-7).
} 
'which stem from controversial theological debates of the 17th and I8th centuries and' - as Jan Assmann now states with surprising clarity - 'are totally unsuitable for the description of ancient religions'. ${ }^{19}$

One could attempt to answer the given questions using many examples stemming from the ancient history of religion, or analyse an endless number of texts written by Christian theologians of antiquity, or turn to the everyday Christian piety of the time, as well as Neoplatonic treatises or pagan magic papyri. But, in doing so, the extensive material of a yetto-be-written monograph on the subject could only be presented in a very abbreviated form, and I will therefore concentrate on a single characteristic example of so-called ancient 'monotheism'. Because I am currently working on a much expanded new publication of an inventory of the inscriptions from antiquity which contain the 'one God' (zĩs $\theta$ cós) formula, ${ }^{20} \mathrm{I}$ will take this formulation and its history as a paradigm, which will help answer both my questions, about what monotheism was, and who the monotheists were, and likewise support my attempt to make certain basic observations on the terminology of 'monotheism' or rather 'polytheism'.

\section{OBSERVATIONS ON MONOTHEISM FROM LATE ANTIQUITY}

Let us take a walk through a small village situated in the vicinity of Damascus in the province of Syria in the fifth century AD. The village is called El Dumeir or Hirbet Ed-Dumèr; its ancient name is unknown today. In antiquity this location would have much resembled the traditional, unchanged, small villages one finds today in the Hauran. The irregular unpaved streets that run through the village are lined, to a great extent, with windowless, one-storey, houses, built mostly of local basalt, sparingly divided into a few rooms, and with roofs made by spanning blocks of basalt supported by an arch or a central supporting column. Today one can still visit such houses, or rather their ruins, in the deserted villages of the Golan, occupied by the Israelis, and in the dead cities of North Jordan. Some have been used continually for almost 5,000 years, and the height of the floors and their low ceilings alone betray the fact that they have been lived in for such an extended period of time. The decoration of the buildings mostly comprises only an ornamented lintel over the door, often still preserved, or utilised in the vicinity for some other purpose. Walking through El Dumeir or Hirbet Ed-Dumèr we confront a basalt lintel and read the inscription

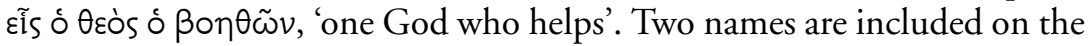

19 Assmann (2003), 49. ${ }^{20}$ Peterson (1926). 
lintel under these lines, which ask us to remember the two persons who commissioned the inscription and - as one can easily assume - also paid for the whole house. On closer scrutiny it is very soon apparent that the

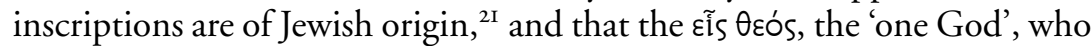
is called upon here, is the God of Abraham, Isaac and Jacob, that is, the God of Israel. Were a Jew of late antiquity to accompany us on our walk, it would have been immediately clear that the acclamation was naturally an abbreviated formula signifying Israel's fundamental profession of faith, the deuteronomistic Sch ma Jisrael, in the Greek form ớkove 'lopaì $\lambda$ kúpios

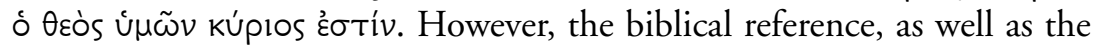
formulation on the lintel ('one God who helps'), make it very clear that the existence of additional gods and divine powers was not denied. Rather, the fact that they also can be effective helpers and as such be addressed as 'Lord' at all was being contested. Analogously, knowledgeable specialists in the field interpret the intentions of many layers in the Old Testament as testifying to monotheism. However, if one is aware of these connections, which in my judgement can neither clearly be termed monotheistic nor polytheistic, and which scholars of religion accordingly categorise a little unfortunately as 'monolatry', then it is questionable if this Hebrew 'monotheism' is really appropriately described in Jan Assmann's convenient formulation of the 'Mosaic distinction'.

After these considerations we continue our walk through the village and come to realise that, if the archaeological evidence does not deceive, this is the only inscription of its kind to be found. We have encountered the inscription عĩs ó $\theta$ còs ó $\beta$ ¡ $\theta \tilde{\omega} v$, 'the one God who helps', written over the entrance of this single Jewish house in the village. We pause for a moment and sit on one of the stones which line a small garden in the village centre, and try to interpret this discovery. It is obvious that the formula eĩs o $\theta$ zòs $\delta \beta \circ \eta \theta \tilde{\omega} v$ served to signify the identity of the two Jewish owners of the house, to differentiate them from the other dwellings, which were probably Christian and pagan. A Jewish fellow believer passing through the village in late antiquity would have known immediately whom he could turn to, where he could expect to be offered hospitality, and where not.

We continue our journey through Syria in late antiquity and travel roughly 250 kilometres from El Dumeir or Hirbet Ed-Dumèr, passing through Damascus and Apameia, to the middle of the Syrian Limestone

2I Brünnow and Domaszewski (I909), no. 37. J.-B. Frey, CIJ II, 89-90, no. 848 interprets the text as a Jewish inscription and corrects Peterson's readings again according to Brünnow; compare also Schwabe (I95I) and the new edition by D. Noy and H. Bloedhorn, IJO III (Syria and Cyprus), 63-5 Syr4I. 
Massif in the north-west of the province. On the high plateau of the Gebel Barîha, we arrive at a somewhat larger ancient village named Dâr Qita. This village, 25 kilometres south of the famous church of St Simeon Stylites, is now forsaken and in ruins. It was a commercial centre on the high plateau massif, from which olive oil and wine, the products grown and produced by the landowners of the small and large estates of the area, were formerly transported to the coast. Because we are interested in the subject of monotheism, we will ignore the three basilicas of the village and again study only the lintels over the entrances of the houses, which are mostly larger complexes with residential buildings and stables surrounded by walls, and sometimes also by shops and stores or small hostels. In doing so, we make some remarkable discoveries. For, if we have correctly counted and carefully studied each lintel that has been preserved over the years, thirteen inscriptions prominently display the familiar formula عĩs $\theta \varepsilon o ́ s$, 'one God'. Strangely enough, these inscriptions all appear to be exclusively Christian: for example, one text dating back to AD 43I reads عĩs $\theta$ còs kaì ó Xpıбтòs aủtoũ kaì tò ớ varied forms of our customary formula from El Dumeir or Hirbet Ed-

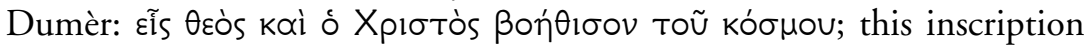
may date to AD 515/16. ${ }^{23}$ Oddly enough, not only the formula with Christ's name appears on Christian houses, but also the simple and very familiar عĩs

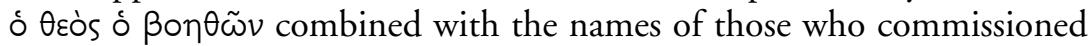
the inscriptions. ${ }^{24} \mathrm{~A}$ comprehensive study has shown that inscriptions including the formula عĩs $\theta$ cós were used especially by newly converted Christians and hence serve as an index of the gradual Christianisation of the North Syrian Limestone Massif in late antiquity. ${ }^{25}$ Thus the formula reading عĩs $\theta$ cós in Dâr Qita and other villages in the Limestone Massif served exactly the same purpose as it did in El Dumeir or Hirbet EdDumèr near Damascus. It marked out certain houses of a village by a sort of 'house sign' in the very same way that one still finds the houses of Christians today, indicated by a plaque depicting St George, and the houses of Moslems, using a vignette displaying the Jerusalem Dome of the Rock. Our South Syrian and North Syrian examples differ only in that in the former case the house of a Jew was made to stand out amongst the Christian residences, and in the latter thirteen houses of Christians were singled out from an incomparably larger number of households inhabited

${ }_{22}$ IGLS II, 536. ${ }^{23}$ IGLS II, 537.
Trombley (1993-4) II, 260.

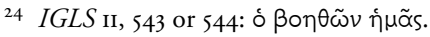


by people of pagan belief. ${ }^{26}$ Therefore, there was no brutal 'liquidation' of polytheistic piety by monotheism, as formulated by Odo Marquard, in Dâr Qita, because the worshippers of gods, whose ability to provide help was doubted by both Christians and Jews alike, were still physically present in the neighbourhood, and they could, by ancient standards, still provide palpable experience of their own divine reality.

But we have not fully exhausted the possibilities of the formula हis $\theta$ cós with these examples. One can find even more evidence for the said connection than has been found in the individual villages of the North Syrian Limestone Massif by investigating a single village in the Holy Land, which has been revealed through the large archaeological excavation of the Church of Mary Theotokos on Mount Gerizim above Nablus/Shechem. This excavation has been carried out for a number of years on the peak of the holy mountain of the Samaritans by the Department of Antiquities for Judea and Samaria, following work commissioned by the Görresgesellschaft that was begun by German archaeologists in the I930s. ${ }^{27}$ A single عĩs $\theta$ rós inscription was published then, but it was not possible to estimate the real extent of the finds until recent years. An Israeli epigrapher has not only published three further $\varepsilon$ ĩs $\theta$ cós inscriptions in recent years, but also verbally confirmed the observation of every attentive visitor of the excavations, that one positively stumbles over عĩs $\theta$ cós inscriptions, especially in the fortresslike buildings which encompass the Church of Mary Theotokos. Even though we still await the final publication of these inscriptions - one can estimate about seventy examples - we have here by far the greatest number of texts containing this formula found in a single location. In general the inscriptions are to be found on floor slabs of single rooms and in the central ambulatory outside the church. On closer scrutiny, it is evident that they are not texts that originally belonged to the still highly impressive Christian church building dating back to late antiquity, but are elements from a Samaritan sacred building, constructed during imperial times on Mount Gerizim and razed to the ground in $\mathrm{AD} 484$ by order of the Byzantine emperor.

At this point I could - perhaps in the style of a travel journal - produce further examples of the use of the عĩs $\theta$ cós formula, which have been

26 Trombley (I993-4) II, 313-I5, esp. 313 ('Appendix v: The “One God” inscriptions'): ‘There can be little doubt that the Christian use of the "One God" formula in the inscription of the Limestone Massif and elsewhere is to be understood as a statement of monotheistic belief vis à vis the villagers' abandonment of polytheism'. Trombley counters the position argued by Jarry (I988).

27 Schneider (1949/5I), esp. 228, 230-I with Plate 9; reprinted in Schneider (1998), esp. 200, 202; cf. also Di Segni (I990). 
unearthed in Israel/Palestine especially in connection with Samaritan synagogues. ${ }^{28}$ By doing so, I would reveal that the monotheistic acclamation عĩs $\theta$ cós also served the Samaritans as a characteristic way of representing their specific identity, which differentiated them from other Jewish, Christian and pagan centres of cult worship in Palestine and in Nablus/Shechem. The invocation 'one God' therefore fulfilled precisely the function that it had at other locations in Syria for those very groups from which the Samaritans had sought to distance themselves for centuries.

My observations on the عĩs $\theta$ cós inscriptions can be rounded off by a reference to the example of milestones in Palestine, which were erected in $\mathrm{AD} 36 \mathrm{I} / 2$ under the rule of the Emperor Julian and which, as they

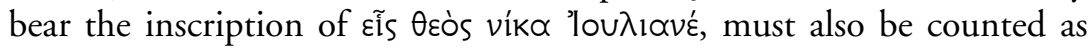
evidence of the fact that the apostate used precisely the عĩs $\theta$ cós formula of the Christians as a form of propaganda against their religion. ${ }^{29}$ Or I could point out a carved gemstone found in Egypt, which introduces an

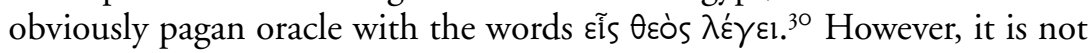
necessary to continue in detail as these examples are more than sufficient to answer both our questions, and lead us to a few final remarks on the usefulness of the category 'monotheism' and the dual terms 'monotheism' 'polytheism' for a history of religion in antiquity.

\section{THE USEFULNESS OF MONOTHEISM FOR THE}

\section{HISTORY OF RELIGION}

We have seen in our examples that at least everyday Jewish 'monotheism' in the South Syrian village of El Dumeir or Hirbet Ed-Dumèr, that of the Christians in Dâr Qita, and that of the Samaritans on Mount Gerizim near Nablus, served the purpose which Odo Marquard contested. It stabilised the individual identity of another distinctive religion within a continuing polytheistic-polymythical environment. We were unable to observe any sign of the tendency towards the intellectual or physical liquidation of polytheistic religions related to professing a monotheistic faith in one god who helps. Rather, the opposite tendency seemed to prevail. The inhabitants in the above-mentioned villages lived peacefully side by side, even after the 'Constantinian transformation'. One can hardly speak of 'liquidation', but at most discern that a certain religious group pointedly professed faith in one single helper, displaying a tendency to emasculate, subordinate and sublimate the gods worshipped by neighbours.

28 Di Segni (1998), 55 .

30 Nock (I940), 3I3.
29 Di Segni (1994), I04, no. 3I; cf. SEG 4I (I99I), I544. 
Correspondingly, the memorable formulation of the 'Mosaic distinction' coined by Jan Assmann does not in reality correspond to the contemporary circumstances. On the contrary, it is exactly the aspect which Assmann holds to be typical for polytheism, its ability to synthesise foreign gods within its own system of myths, which in fact characterises how Jews, Christians and Samaritans dealt with the gods of their pagan neighbours. They were regarded as ultimately helpless and weak divine powers, simply as demons, but their existence was by no means liquidated. What is more, Jews, Christians and Samaritans would of course have differentiated themselves more pointedly and perhaps more exactly than in pagan polytheism, but did every Thessalian farmer really worship all the gods of the Greek pantheon? Did a simple citizen who farmed land in the vicinity really visit Artemis one morning, Apollo of Claros the next, and go to the temple of the deified emperor Hadrian the day after? Does not the alleged clearcut differentiation between 'monotheism' and 'polytheism' become more blurred as we adjust the optics and view the situation more precisely? On closer observation were not polytheists as well as monotheists sometimes violent and sometimes peaceable? Do not other factors, such as the political and economic circumstances of the times, play a much more decisive role when trying to explain the reasons behind the liquidation and rise of religions? As for the headword 'monolatry', the worship of only one god, while it still acknowledges the existence of other gods and demonic beings, are not all cats grey anyway?

The exemplary finds in the Near East of late antiquity should warn us not to overestimate the efficiency of the category 'monotheism' and its counterpart 'polytheism'. These paired terms have been in use since the seventeenth century, but since then have yet to play a dominant role in religious and theological history. It was probably Friedrich Schleiermacher in the introduction to the second edition of the Glaubenslehre (I830-I) who initially moulded the notion and matter of 'monotheism'31 into a characteristic that identified Judaism, Christianity and Islam. ${ }^{32}$ Incidentally, this explains his very critical position in relation to the Church's teachings on the Trinity, in which he detects the 'unconscious echo of the heathen'. Put in less genteel wording, the remaining stock of polytheism required 'new treatment' and 'remodelling', and this was to be found embryonically in

${ }^{31}$ Cf. two more recent definitions: Bloch (2000), 375: 'Glauben an die Existenz eines einzigen Gottes im Gegensatz zu Polytheismus und Henotheismus'; Schwöbel (1994), 257: “"Monotheismus” bezeichnet im allgemeinen eine Interpretation des Göttlichen, die dieses als wesentlich eine, einzig und einheitliche, in genauer zu bestimmendem Sinn personhafte... Wirklichkeit darstellt, die auf das welthafte Seiende als deren Grund und Ziel bezogen ist.'

32 Schleiermacher (1960), \$8. It displayed, however, varying degrees in Judaism and Islam; cf. the observations made by Schwöbel (1994), 257. 
the theology of the Trinity. ${ }^{33}$ This view converges in a sense with that of Odo Marquard. So, if one critically reconsiders the function and efficiency of the dual terms 'monotheism' - 'polytheism', ${ }^{34}$ the results would be in no way as crucial for reconstructing the history of religion in antiquity as has been concluded by certain researchers, even by whole generations of researchers, who have eagerly sought out evidence for polytheism as practised by monotheists in late antiquity.

The evidence of inscriptions found among ordinary Christians indicates that the confined limits of a clearly defined concept of monotheism, to which excessive attention has been paid in the widely inculcated tradition introduced by Schleiermacher, did not exist in late antiquity. The overall picture in later antiquity was varied and colourful. We may recall the problematical role played by the angels in monotheistic religions. ${ }^{35}$ As early as the nineteenth century some scholars of religion believed that the intensive worship of angels in Judaism weakened monotheism and thereby, so to speak, provided suitable conditions for the Christian theology of the Trinity. ${ }^{36}$ This view has also, of course, been strongly refuted since. ${ }^{37}$ Inscriptions in particular reveal how popular the worship of angels was in the everyday life of ancient times amongst Jews and Christians alike, ${ }^{38}$ but one could also demonstrate the commonplace 'polytheism' of the 'monotheists' by citing the many magic texts which were used by the Jews, Christians and Samaritans of antiquity as a matter of course. I will abstain from citing further evidence for the 'routine polytheism' of many ancient 'monotheists', because here too our examples are already enough to illustrate the basic thesis. ${ }^{39}$ Additionally, theoretical reflection in the time of the Roman Empire was often not at all concerned with our modern questions about the singularity of God in opposition to 'polytheism', but, as many Middle Platonic and Neoplatonic texts suggest, ${ }^{40}$ with the simpler question of what stands at the beginning of all things, a single principle, a final reason, or even a dualistic principle. The function of the dual categories of 'monotheism' - 'polytheism' should be reviewed, not

33 Schleiermacher (1960), \$172.

34 According to Julian, Contra Galilaeos 72.20-I cited by Cyril of Alexandria, In Julianum 9.306B, the question concerning monotheism and polytheism is 'a trivial matter'.

35 Corbin (198I). $\quad 36$ Bousset (I926), 302-57; see, most recently, Koch (1994).

37 Hurtado (2003), 24-7 and also 4I: "The "weakened monotheism" of post-biblical Judaism described by Bousset and others is an erroneous construct'; Hayman (I991).

38 Leclercq (1924), 2I44-53. 39 For Egypt see Vinzent (I998), 43-6.

40 For example, cf. the following passage from the sixth century: Olympiodorus, In Platonis Gorgiam

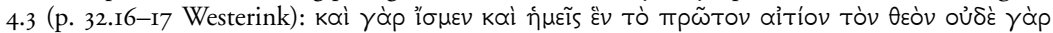
$\pi \circ \lambda \lambda \dot{\alpha} \pi \rho \tilde{\omega} \tau$ ('And we also know that the first cause of all things is one and that it is God. Therefore there cannot be many first causes'). 
only because they are relatively recent coinages, but also because of their limited explanatory power. This applies by no means only to the social history of religion, but also particularly to the history of religion and ideas in general.

My examples have shown that basing our understanding of the relationship between 'monotheism' and 'polytheism' as corresponding to a conflict between an open and a totalitarian society misses the truth at least in the case of the historical circumstances of antiquity. One may assume that the case was similar in the earlier eras of Israeli and Jewish religious history. I have also voiced considerable doubts about the efficiency of the terms 'monotheism' and 'polytheism' within history and religious studies. This result leads us to a final question. How could one construct such clearly demarcated patterns for religions?

It is my belief that imposition of such terminology, which fits the historical truth only under very limited conditions, is linked with the very one-sided orientation to be found in many studies of religious history which - to put it succinctly - impose a bias towards intellectual history. This is also the case with many works written by theologians and ecclesiastical historians, who approach the subject matter from the viewpoint of dogmatic and theological history. The sensitive subject of 'monotheism' 'polytheism' is treated purely in the context of a certain social class of ancient society, against the background of views held by erudite teachers and highly educated cultic functionaries. The historical picture that is conveyed remains correspondingly tendentious.

Jan Assmann's extremely erudite monograph displays a similar bias, not so much in representing the history of ancient mentality, as implied by the subtitle, but rather in presenting a prehistory of a previous European mentality, and thus demonstrating the impressive self-enlightenment of a member of the German professorial class concerning the light and dark sides of his identification as a German and European academic. From this viewpoint, all the above-mentioned patterns are particularly relevant to intellectual history and to a mentality which is not to be underestimated, even though we have vehemently disputed their relevance for approaching the history of ancient religion. They are relevant in the present day, when, for example, the construction of clearly differentiated 'monotheism' and 'polytheism' is used to enlist support for religious and political tolerance and to preserve the basic principles of democracy based on the rule of law. It would not at all become a theologian to contradict such an argument. 


\section{Bibliography}

Ahn, G. (1993) “"Monotheismus" - "Polytheismus": Grenzen und Möglichkeiten einer Klassifikation von Gottesvorstellungen', in Mesopotamia - Ugaritica Biblica: Festschrift für K. Bergerhof, ed. M. Dietrich and O. Loretz. Neukirchen and Vluyn: I-24.

Albert, K. (1980) Griechische Religion und platonische Philosophie. Hamburg.

Alföldy, G. (1997) 'Die Mysterien von Panóias (Vila Real, Portugal)', Madrider Mitteilungen 38: 197-246.

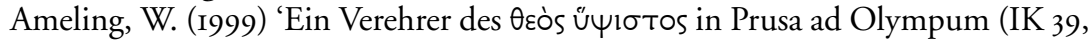
II5)', EA 31: I05-8.

(2004) Inscriptiones Judaicae Orientis II. Kleinasien. Tübingen.

Ando, C. (2003) Introduction to Part Iv, in Roman Religion, ed. C. Ando. Edinburgh: I4I-6.

(2005) 'Interpretatio Romana', CPh Ioo: 4I-5I.

(2008) The Matter of the Gods. Berkeley.

Andresen, C. (1955) Logos und Nomos: Die Polemik des Celsus wider das Christentum. Berlin.

Asad, T. (1993) Genealogies of Religion: Discipline and reasons of power in Christianity and Islam. Baltimore and London.

Assmann, J. (1997) Moses the Egyptian: The memory of Egypt in western monotheism. Cambridge, Mass.

(1998) Moses der Ägypter: Entzifferung einer Gedächtnisspur. Munich and Vienna; Frankfurt a.M.

(1999) 'Monothéisme et mémoire: le Moïse de Freud et la tradition biblique', Annales 54: IOII-26, reprinted in Assmann (2000), 62-80.

(2000) Religion und kulturelles Gedächtnis: Zehn Studien. Munich. English translation Religion and Cultural Memory, trans. R. Livingstone, Stanford 2005 .

(2003) Die mosaische Unterscheidung oder der Preis des Monotheismus, Munich and Vienna.

(2004) 'Monotheism and Polytheism', in Religions of the Ancient World: A guide, ed. S. I. Johnston. Cambridge, Mass. and London: I7-3I. 
Athanassiadi, P. (I999) 'The Chaldaean oracles: theology and theurgy', in Athanassiadi and Frede (I999), I49-83.

(forthcoming) 'The gods are God: polytheistic cult and monotheistic theology in the world of late antiquity', Collection Eranos I4.

Athanassiadi, P. and Frede, M. (eds.) (I999, corrected reprint 2002) Pagan Monotheism in Late Antiquity. Oxford.

Aubriot, D. (2005) 'L'invocation $\mathrm{au}(\mathrm{x}) \operatorname{dieu}(\mathrm{x})$ dans la prière grecque: contrainte, persuasion ou théologie?', in Belayche and others (2005), 473-90.

Auffarth, C. (1993) 'Henotheismus/Monolatrie', in Handbuch religionswissenschaftlicher Grundbegriffe III, ed. H. Cancik and others. Stuttgart, Berlin and Cologne: 104-5.

Avagianou, A. (2002) 'Physiology and mysticism at Pherai: the funerary epigram for Lykophron', Kernos 15: 75-89.

Avi Yonah, M. (1944) 'Greek inscriptions from Ascalon, Jerusalem, Beisan and Hebron', QDAP io: I60-9.

Baker, M. (2005) 'Who was sitting in the theatre at Miletos: an epigraphical application of a novel theory', Journal for the Study of Judaism 36: 397-4I6.

Battifol, P. (I929) La paix constantinienne et le catholicisme. Paris.

Baumeister, Th. (1978) 'Gottesglaube und Staatsauffassung - ihre Interdependenz bei Celsus und Origenes', Theologie und Philosophie 53: I6I-78.

Beard, M., North, J. and Price, S. (1998) Religions of Rome, 2 vols. Cambridge.

Beck, R. (2004) 'Four men, two sticks and a whip: image and doctrine in a Mithraic ritual', in Theorizing Religions Past: Archaeology, history and cognition, ed. H. Whitehouse and L. H. Martin. Walnut Creek, Calif.: 87-IO3.

(2006) The Religion of the Mithras Cult in the Roman Empire. Oxford.

Belayche, N. (200I) Iudaea Palaestina: The pagan cults in Roman Palestine (second to fourth century). Tübingen.

(2003) 'En quête de marqueurs des communautés “religieuses” gréco-romaines', in Les communautés religieuses dans le monde gréco-romain: essais de définition, ed. N. Belayche and S. C. Mimouni. Turnhout: 9-20.

(2005a) 'Hypsistos: une voie de l'exaltation des dieux dans le polythéisme grécoromain', Archiv für Religionsgeschichte 7: 34-55.

(2005b) 'De la polysémie des épiclèses: Hypsistos dans le monde gréco-romain', in Belayche and others (2005), 427-42.

(2005c) “"Au(x) dieu(x) qui règne(nt) sur ... ": basileia divine et fonctionnement du polythéisme dans l'Anatolie impériale', in Pouvoir et religion dans le monde romain: en hommage à Jean-Pierre Martin, ed. A. Vigourt and others. Paris: 257-69.

(2006a) 'Quel regard sur les paganismes d'époque impériale?', Anabases 3: II-26.

(2006b) 'Les stèles dites de confession: une religiosité originale dans l'Anatolie impériale?', in The Impact of Imperial Rome on Religions, Ritual, and Religious Life in the Roman Empire, ed. L. de Blois, P. Funke and J. Hahn. Leiden and Boston: 73-8I. 
(2007a) 'Les dieux "nomothètes": Oracles et prescriptions religieuses à l'époque romaine impériale', $R H R$ 224: I7I-9I.

(2007b) 'Rites et "croyances" dans l'épigraphie religieuse de l'Anatolie impériale', in Rites et croyances dans le monde romain, ed. J. Scheid (Entretiens Fondation Hardt 53). Geneva-Vandoeuvres: 73-II5.

(2008) 'Du texte à l'image: les reliefs des stèles "de confession" d'Anatolie', in Image et religion, ed. S. Estienne, C. Pousadoux and others (CEFR). Rome and Naples: I8I-94.

Belayche, N. and others (eds.) (2005) Nommer les dieux: théonymes, épithètes, épiclèses dans l'Antiquité. Rennes.

Bell, C. (1992) Ritual Theory, Ritual Practice. New York and Oxford.

Bendlin, A. (2000) 'Looking beyond the civic compromise: religious pluralism in late republican Rome', in Religion in Archaic and Republican Rome: Evidence and experience, ed. E. Bispham and C. Smith. Edinburgh: II5-35.

(200I) 'Rituals or beliefs? Religion and the religious life of Rome', SCI 20: I9I-208.

(2006a) 'Vom Nutzen und Nachteil der Mantik: Orakel im Medium von Handlung und Literatur in der Zeit der Zweiten Sophistik', in Texte als Medium und Reflexion von Religion im römischen Reich, ed. D. Elm von der Osten, J. Rüpke and K. Waldner. Stuttgart: 159-207.

(2006b) 'Nicht der Eine, nicht die Vielen: zur Pragmatik religiösen Verhaltens in einer polytheistischen Gesellschaft am Beispiel Roms', in Spieckermann and Kratz (2006), 279-3II.

Bernand, E. (1969) Inscriptions métriques de l'Egypte gréco-romaine. Paris.

Berns, C. (2006) 'Konkurrierende Zentren: Überlegungen zur religiösen Repräsentation in Ephesos und den Städten der Provinz Asia in der Kaiserzeit', in Zentralität und Religion, ed. H. Cancik and others. Tübingen: 273-308.

Berrens, S. (2004) Sonnenkult und Kaisertum von den Severern bis zu Constantin I (I93-337 n. Chr.). Stuttgart.

Bianchi, U. and Vermaseren, M. (eds.) (I98I) La soteriologia dei culti orientali nell'impero Romano. Leiden.

Birley, E. (I974) 'Cohors I Tungrorum and the oracle of the Clarian Apollo', Chiron 4: $5 \mathrm{II}-\mathrm{I} 3$.

Bloch, R. (2000) 'Monotheism', in Der Neue Pauly viII: 375-8.

Bonner, C. (1950) Studies in Magical Amulets Chiefly Graeco-Egyptian. Ann Arbor, Mich.

Bonner, C. and Nock, A. D. (1948) 'Neotera', HThR 4I: 213-15.

Bonnet, C. and Motte, A. (eds.) (1997) Les syncrétismes religieux dans le monde méditerranéen antique: Actes du colloque international en l'honneur de Franz Cumont à l'occasion du cinquantième anniversaire de sa mort. Rome.

Borgeaud, P. (2003) Aux origines de l'histoire des religions. Paris.

Boudon-Millot, V. and Pietrobelli, A. (2005) 'Galien resuscité: édition princeps du texte grec du De propriis placitis', REG II8: I65-2I3. 
Boulogne, J. (1997) 'Hénothéisme et polythéisme sous les Antonins: l'imaginaire religieux de Plutarque', Euphrosyne: 28I-93.

Bousset, W. (1926) Die Religion des Judentums im späthellenistischen Zeitalter, 3rd edn. Tübingen.

Bowen, J. R. (2002) Religions in Practice: An approach to the anthropology of religion. Boston.

Bowersock, G. (2002) 'The highest god with particular reference to North-Pontus', Hyperboreus 8: 353-63.

(2007) 'CIRB no. 7I and recent debates', in Une koinè pontique: cités grecques, sociétés indigènes et empires mondiaux sur le littoral nord de la Mer Noire, ed.

A. Bresson and others. Bordeaux: 25I-4.

Boys-Stones, G. R. (200I) Post-Hellenistic Philosophy. Oxford.

Bradbury, S. (I995) 'Julian's pagan revival and the decline of blood sacrifice', Phoenix 49: 33I-56.

Bremmer, J. N. (1995) 'The family and other centres of religious learning in antiquity', in Centres of Learning, ed. J. W. Drijvers and A. A. MacDonald. Leiden: $29-38$.

(2002a) The Rise and Fall of the Afterlife. London and New York.

(2002b) 'How old is the ideal of holiness (of mind) in the Epidaurian temple inscription and the Hippocratic oath?', ZPE I4I: I06-8.

Bricault, L. (2005a) Recueil des inscriptions concernant les cultes isiaques (RICIS) I-II. Corpus; III. Planches (Mémoires de l'Académie des Inscriptions et BellesLettres XxxI). Paris.

(2005b) 'Zeus Hélios Mégas Sarapis', in La langue dans tous ses états: Michel Malaise in honorem, ed. C. Cannuyer (Acta Orientalia Belgica I8). Brussels: 243-54.

Brisson, L. (1990) 'Orphée et l'orphisme à l'époque impériale: témoignages et interprétations philosophiques de Plutarque à Jamblique', in $A N R W$ II.36.4: 2867-93I.

Brixhe, C. and Hodot, R. (1988) L'Asie Mineure du nord au sud. Nancy.

Brown, P. (1963) 'Saint Augustine', in Trends in Medieval Political Thought, ed. B. Smalley. Oxford: I-2I, reprinted in Brown (1972), 22-45.

(1972) Religion and Society in the Age of Saint Augustine. London.

Brox, N. (I982) 'Mehr als Gerechtigkeit: die außenseiterischen Eschatologien des Markion und Origenes', Kairos 24: I-I6, reprinted in Brox (2000), $385-403$.

(2000) Das Frühchristentum: Schriften zur historischen Theologie, ed. F. Dünzl, A. Fürst and F. R. Prostmeier. Freiburg, Basle and Vienna.

Brünnow, R.-E. and Domaszewski, A. von (1909) Die Provincia Arabia auf Grund zweier in den Jahren I897 und I898 unternommenen Reisen und Berichte III. Strasbourg.

Burkert, W. (I977) Griechische Religion der archaischen und klassischen Epoche (Religionen der Menschheit I5). Stuttgart etc.

Busine, A. (2005) Paroles d'Apollon: pratiques et traditions oraculaires dans l'Antiquité tardive (IIe-vie siècle). Leiden. 
Cadotte, A. (2002-3) 'Pantheus et dii deaeque omnes: les formules de synthèses divines en Afrique du Nord', Antiquités africaines 38-9: 55-72.

Cassirer, E. (1946) Language and Myth. London. (German original: Leipzig, 1925.)

Cerutti, M. V. (2009) "Pagan Monotheism”? Towards a historical typology', in Mitchell and Van Nuffelen (2009), I5-32.

Chadwick, H. (1953) Origen. Contra Celsum. Cambridge.

(1965) Origen: Contra Celsum. Translation, with introduction and notes, 2nd edn. Cambridge.

Chaniotis, A. (1997) 'Reinheit des Körpers - Reinheit der Seele in den griechischen Kultgesetzen', in Schuld, Gewissen und Person, ed. J. Assmann and T. Sundermeier. Gütersloh: I42-79.

(1998) 'Willkommene Erdbeben', in Stuttgarter Kolloquium zur historischen Geographie des Altertums 6: Naturkatastrophen in der antiken Welt, ed. E. Olshausen and H. Sonnabend. Stuttgart: 404-I6.

(2000) 'Das Jenseits - eine Gegenwelt?', in Gegenwelten zu den Kulturen der Griechen und der Römer in der Antike, ed. T. Hölscher. Munich and Leipzig: I59-8I.

(2002a) 'The Jews of Aphrodisias: new evidence and old problems', SCI 2I: 209-42.

(2002b) 'Zwischen Konfrontation und Interaktion: Christen, Juden und Heiden im spätantiken Aphrodisias', in Patchwork: Dimensionen multikultureller Gesellschaften, ed. C. Ackermann and K. E. Müller. Bielefeld: 83-I28.

(2002c) 'Old wine in a new skin: tradition and innovation in the cult foundation of Alexander of Abonouteichos', in Tradition and Innovation in the Ancient World, ed. E. Dabrowa. Krakow: 67-85.

(2003) 'Negotiating religion in the cities of the eastern Roman empire', Kernos I6: I77-90.

(2004a) 'Under the watchful eyes of the gods: aspects of divine justice in hellenistic and Roman Asia Minor', in The Greco-Roman East: Politics, culture, society, ed. S. Colvin. Cambridge: $\mathrm{I}-43$.

(2004b) 'New inscriptions from Aphrodisias (I995-200I)', AJA I08: 377-4I6.

(2006) 'Rituals between norms and emotions: rituals as shared experience and memory', in Rituals and Communication in the Graeco-Roman World, ed. E. Stavrianopoulou. Liège: $2 \mathrm{II}-38$.

(2007) 'Religion und Mythos in der hellenistischen Welt', in Kulturgeschichte des Hellenismus, ed. G. Weber. Stuttgart: $139-57$ and 448-54.

(2008a) 'Konkurrenz von Kultgemeinden im Fest', in Festrituale: Diffusion und Wandel im römischen Reich, ed. J. Rüpke. Tübingen: 67-87.

(2008b) 'Acclamations as a form of religious communication', in Die Religion des Imperium Romanum: Koine und Konfrontationen, ed. H. Cancik and J. Rüpke. Tübingen: 199-2I8.

(2009) 'Ritual performances of divine justice: the epigraphy of confession, atonement, and exaltation in Roman Asia Minor', in From Hellenism to Islam: Cultural and linguistic change in the Roman Near East, ed. H. Cotton and others. Cambridge: II5-53. 
(20I0) 'The ithyphallic hymn for Demetrios Poliorcetes and Hellenistic religious mentality', in Royal Cult and Imperial Worship from Classical to Late Antiquity, ed. P. P. Iossif and A. S. Chankowski (Acts of the International Conference Organized by the Belgian School at Athens (I-2 November 2007)). Leuven.

(forthcoming) 'Listening to stones: orality and emotion in ancient inscriptions', in Proceedings of the I3th International Congress of Greek and Latin Epigraphy, ed. J. K. Davies and J. J. Wilkes. Oxford.

Chaniotis, A. and Chiai, G. F. (2007) 'Die Sprache der religiösen Kommunikation im römischen Osten: Konvergenz und Differenzierung', in Antike Religionsgeschichte in räumlicher Perspektive, ed. J. Rüpke. Tübingen: II7-24.

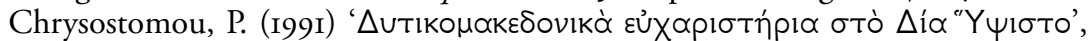
To Archaiologiko Ergo sten Makedonia kai Thrake (Thessalonica) 5: 9I-9.

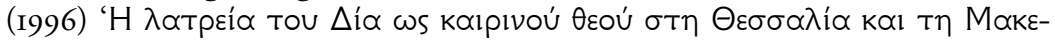
Sovía', Archaiologikon Deltion 44-6 (I989-9I, published 1996): 2I-72.

Cobb, W. F. (1895) Origines Judaicae. London.

Cohen, H. (I915) Der Begriff der Religion im System der Philosophie. Giessen.

Cole, S. (200I) 'The dynamics of deification in Horace's Odes I-3', in Between Magic and Religion: Interdisciplinary studies in ancient Mediterranean religion and society, ed. S. R. Asirvatham, C. O. Pache and J. Watrous. Lanham, Md. and Oxford: 67-9I.

Colin, J. (1965) Les villes libres de l'Orient gréco-romain et l'envoi au supplice par acclamations populaires. (Collection Latomus I54) Brussels.

Collas-Heddeland, E. (1995) 'Le culte impérial dans la compétition des titres sous le Haut-Empire: une lettre d'Antonin aux Ephésiens', $R E G$ Io8: 4IO-29.

Colpe, C. and Löw, A. (1993) 'Hypsistos (theos)', in Reallexicon zum Antiken Christentum Xvi: I035-55.

Corbin, H. (198I) Le paradoxe du monothéisme. Paris.

Crowfoot, J. W., Crowfoot, G. M. and Kenyon, K. M. (1954) Samaria-Sebaste: Reports of the work of the joint expedition in I93I-I933 and of the British Expedition in I935 III. The Objects at Samaria. London.

Cudworth, R. (I678) The True Intellectual System of the Universe: The first part; wherein, all the REASON and PHILOSOPHY of ATHEISM is confuted; AND its IMPOSSIBILITY demonstrated. London (reprinted Stuttgart 1964).

Cumont, F. (1924) Les religions orientales dans le paganisme romain, 4 th edn. Paris. Davies, J. P. (2004) Rome's Religious History. Cambridge.

de Hoz, M. Paz (I99I) 'Theos Hypsistos in Hierokaisareia', EA I8: 75-7.

(1997) 'Henoteísmo y magia en una inscripción de Hispania', ZPE I18: 227-30.

(1999) Die lydischen Kulte im Lichte der griechischen Inschriften (Asia Minor Studien 36). Bonn.

(2002) 'Men, un dios lunar, con corona de rayos', Mene 2: I89-20I.

Decharme, P. (1966) La critique des traditions religieuses chez les Grecs. Paris.

Decourt, J.-C. (2004) Inscriptions grecques de la France. Lyon.

Delaporte, L. (1923) Catalogue des cylindres orientaux du Musée du Louvre II. Paris.

Delling, G. (1964/5) 'Die Altarinschrift eines Gottesfürchtigen in Pergamon', Novum Testamentum 7: 73-80. 
Di Segni, L. (1990) 'The Church of Mary Theotokos on Mount Gerizim: the inscriptions', in Christian Archeology in the Holy Land: New discoveries, ed. G. C. Bottini, L. Di Segni and E. Alliata. Jerusalem: 343-50.

(1994) 'EI $\Sigma$ $\Theta E O \Sigma$ in Palestinian inscriptions', SCI I3: 94-II5.

(I998) 'The Samaritans in Roman-Byzantine Palestine: some misapprehensions', in Religious and Ethnic Communities in Later Roman Palestine, ed. H. Lapin. Bethesda, Md.: 5I-66.

Dillon, J. (1999) 'Monotheism in the gnostic tradition,' in Athanassiadi and Frede (1999), 69-79.

Dörrie, H. (1967) 'Die platonische Theologie des Celsus in ihrer Auseinandersetzung mit der christlichen Theologie, auf Grund von Origenes, c. Celsum 7.42ff.', Nachrichten der Akademie der Wissenschaften in Göttingen, Phil.-hist. Klasse 2: 19-55, reprinted in Dörrie (1976): 229-62.

(1976) Platonica minora. Munich.

Dräger, M. (1993) Die Städte der Provinz Asia in der Flavierzeit. Frankfurt.

Drew-Bear, T., Thomas, C. M. and Yildizturan, M. (1999) Phrygian Votive Steles. Ankara.

Droge, A. J. (2006) 'Self-definition vis-à-vis the Graeco-Roman world', in The Cambridge History of Christianity I. Origins to Constantine. Cambridge: 23044 .

Dumézil, G. (I970) Archaic Roman Religion. Chicago and London.

Durand, J.-L. and Scheid, J. (1994) "Rites" et "religion": remarques sur certains préjugés des historiens de la religion des Grecs et des Romains', Archives de Sciences Sociales des Religions 82: 23-43.

Edwards, M. (2000) Review of Athanassiadi and Frede (1999), JThS 51: 339-42.

(2004) 'Pagan and Christian monotheism in the age of Constantine', in Approaching Late Antiquity: The transformation from early to late empire, ed. S. Swain and M. Edwards. Oxford: 2II-34.

Ehrenberg, V. (1965) 'Athenischer Hymnus auf Demetrios Poliorketes', in Polis und Imperium. Zurich and Stuttgart: 503-I9.

Engelmann, H. (200I) 'Inschriften und Heiligtum', in Der Kosmos der Artemis von Ephesos, ed. U. Muss. Vienna: 33-44.

Engster, D. (2003) Konkurrenz oder Nebeneinander: Mysterienkulte in der hohen römischen Kaiserzeit. Munich.

Erbse, H. (1995) Theosophorum Graecorum fragmenta. Stuttgart and Leipzig.

Fédou, M. (1988) Christianisme et religions païennes dans le Contre Celse d'Origène. Paris.

Feeney, D. (1998) Literature and Religion at Rome: Cultures, contexts, and beliefs. Cambridge.

Feldman, L. H. (1993) Jew and Gentile in the Ancient World: Attitudes and interactions from Alexander to Justinian. Princeton.

Flusser, D. (1975) 'The great goddess of Samaria', IEJ 25: 13-20.

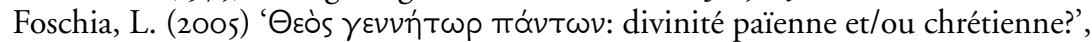
in Belayche and others (2005), 453-66. 
Fowden, G. (I99I) 'Constantine’s porphyry column: the earliest literary allusion', JRS 8I: II9-3I.

(1993) From Empire to Commonwealth: The consequences of monotheism in late antiquity. Princeton.

Fowler, W. Warde (1912) The Religious Experience of the Roman People. London.

François, G. (1957) Le polythéisme et l'emploi au singulier des mots THEOS, $D A I M O \hat{N}$ dans la littérature grecque d'Homère à Platon. Paris.

Franken, R. (2002) 'Lampen für die Götter: Beobachtungen zur Funktion der sogenannten Vexillumaufsätze', $M D A I(I)$ 52: 369-8I.

Frankfurter, D. (1998) Religion in Roman Egypt: Assimilation and resistance. Princeton.

Fraser, P. M. (1962) 'Two inscriptions from Cyrenaica', Annals of the British School at Athens 57: 25-7.

Frede, M. (1997) 'Celsus' attack on the Christians', in Philosophia Togata II. Plato and Aristotle at Rome, ed. J. Barnes and M. Griffin. Oxford: 218-40.

(1999) 'Monotheism and pagan philosophy in later antiquity', in Athanassiadi and Frede (I999), 4I-68.

Frede, M. and Athanassiadi, P. (1999) 'Introduction', in Athanassadi and Frede (1999), 7-20.

Fuhrer, Th. (1997) 'Die Platoniker und die civitas dei', in Augustinus: De civitate dei (Klassiker auslegen II), ed. C. Horn. Berlin: 87-ı08.

Fürst, A. (2000) 'Laßt uns erwachsen werden! Ethische Aspekte der Eschatologie des Origenes', Theologie und Philosophie 75: 32I-38.

(2004a) "Wer das glaubt, weiß gar nichts": eine spätantike Debatte über den Universalanspruch des christlichen Monotheismus', Orientierung 68: I38-4I.

(2004b) 'Monotheismus und Gewalt: Fragen an die Frühzeit des Christentums', Stimmen der Zeit 222: 52I-3I.

(2006a) 'Christentum im Trend: monotheistische Tendenzen in der späten Antike', Zeitschrift für antikes Christentum 9: 496-523.

(2006b) 'Seneca - ein Monotheist? Ein neuer Blick auf eine alte Debatte', in Der apokryphe Briefwechsel zwischen Seneca und Paulus (SAPERE II), ed. A. Fürst and others. Tübingen: 85-IO7.

(2007) 'Wahrer Gott - wahre Gerechtigkeit: politische Implikationen des Monotheismus in der Spätantike', in Palmer (2007), 25I-82.

Gallini, C. (1970) Protesta e integrazione nella Roma antica. Bari.

Gerson, L. (1990) God and Greek Philosophy: Studies in the early history of natural theology. London.

Girone, M. (2003) 'Una particolare offerta die chiome', EA 35: 2I-42.

Gladigow, B. (1993) 'Polytheismus', in Handbuch religionswissenschaftlicher Grundbegriffe Iv, ed. H. Cancik and others. Stuttgart, Berlin and Cologne: 32I-30.

Gnuse, R. K. (1997) No Other Gods: Emergent monotheism in Israel. Sheffield.

(1999) 'The emergence of monotheism in ancient Israel: a survey of recent scholarship', Religion 29: 315-36. 
Gödde, S. (2003) 'Emotionale Verschiebungen: zur Bedeutung der euphemia im griechischen Ritual', in Die emotionale Dimension antiker Religiosität, ed. A. Kneppe and D. Metzler. Münster: 2I-46.

Goldhill, S. (2006) 'Religion, Wissenschaftlichkeit und griechische Identität im römischen Kaiserreich,' in Texte als Medium und Reflexion von Religion im römischen Reich, ed. D. Elm von der Osten, J. Rüpke and K. Waldner. Stuttgart: $125-40$.

Goodman, M. (1994) Mission and Conversion: Proselytizing in the religious history of the Roman Empire. Oxford.

(2003) 'The Jewish image of God in late antiquity', in Jewish Culture and Society under the Christian Roman Empire, ed. R. Kalmin and S. Schwartz. Leuven: I33-45, reprinted in Goodman (2007), 205-I7.

(2007) Judaism in the Roman World: Collected essays. Leiden and Boston.

Gordon, R. (200I) 'Ritual and hierarchy in the mysteries of Mithras', Antigüedad: Religiones y Sociedades 4: 245-73.

(2003) (with J. M. Reynolds) 'Roman inscriptions 1995-2000', JRS 93: 212-94.

Goukowsky, P. (2002) 'Sur une épigramme de Thespies', in L'Épigramme de l'Antiquité au XvIIe siècle ou Du ciseau à la pointe, ed. J. Dion. Nancy: 2I746.

Gounaropoulou, L. and Hatzopoulos, M. (1998) Epigraphes kato Makedonias I. Epigraphes Beroias (=I. Beroea). Athens.

Graf, F. (1985) Nordionische Kulte: Religionsgeschichtliche und epigraphische Untersuchungen zu den Kulten von Chios, Erythrai, Klazomenai und Phokaia. Rome.

(1996) Gottesnähe und Schadenzauber: Die Magie in der griechisch-römischen Antike. Munich.

Graf, F. and Johnston, S. I. (2007) Ritual Texts for the Afterlife: Orpheus and the Bacchic gold tablets. London and New York.

Gragg, D. L. (2004) 'Old and new in Roman religion: a cognitive account', in Theorizing Religions Past: Archaeology, history and cognition, ed. H. Whitehouse and L. H. Martin. Walnut Creek, Calif: 69-86.

Grandjean, Y. (I975) Une nouvelle arétalogie d'Isis à Maronée (EPRO 49). Leiden.

Gruen, E. (I990) 'The Bacchanalian affair', in Studies in Greek Culture and Roman Policy. Leiden: $34-78$.

Habicht, C. (1969) Altertümer von Pergamon Band viII.3. Die Inschriften des Asklepieions. Berlin.

Hall, A. S. (1977) 'A sanctuary of Leto at Oenoanda', $A S$ 27: 193-7.

(I978) 'The Klarian oracle at Oenoanda', ZPE 32: 263-8.

Harland, P. A. (2003) Associations, Synagogues and Congregrations: Claiming a place in Mediterranean society. Minneapolis.

Harrison, S. J. (200o) Apuleius: A Latin sophist. Oxford.

Hartung, J. A. (1836) Die Religion der Römer. Erlangen.

Hawthorn, G. (I991) Plausible Worlds: Possibility and understanding in history and the social sciences. Cambridge. 
Hayman, P. (I99I) 'Monotheism - a misused word in Jewish studies?', JJS 4I: I-I 5 .

Heller, A. (2006) 'Les bêtises des Grecs': conflits et rivalités entre cités d'Asie et de Bithynie à l'époque romaine (I29 a.C.-235 p.C.) (Ausonius, Scripta Antiqua I7). Bordeaux.

Henig, M. and McGregor, A. (2004) Catalogue of the Engraved Gems and FingerRings in the Ashmolean Museum II. Roman (BAR International Series I332). Oxford.

Herrero de Jáuregui, M. (2009) 'Orphic god(s): theogonies and hymns as vehicles for monotheism', in Mitchell and Van Nuffelen (2009), 77-99.

Herrmann, P. (1978) 'Men, Herr von Axiotta', in Studien zur Religion und Kultur Kleinasiens (EPRO 66/2). Leiden: 4I5-23.

(1998) Inschriften von Milet vi.2. Berlin.

Herrmann, P. and Malay, H. (2007) New Documents from Lydia. Vienna.

Herrmann, P. and Polatkan, K. Z. (1969) Das Testament des Epikrates und andere neue Inschriften aus dem Museum von Manisa. Vienna.

Heyking, J. von (I999) 'A headless body politic? Augustine's understanding of a populus and its representation', History of Political Thought 20: 549-74.

Hirsch-Luipold, R. (2005) 'Der eine Gott bei Philon von Alexandrien und Plutarch', in Gott und die Götter bei Plutarch, ed. R. Hirsch-Luipold (RVV $54)$. Berlin and New York.

Hirschmann, V.-E. (2005) Horrenda secta: Untersuchungen zum frühchristlichen Montanismus und seinen Verbindungen zur paganen Religion Phrygiens (Historia Einzelschriften I79). Stuttgart.

Hornung, E. (1986) Les dieux de l'Égypte: l'un et le multiple. Paris. (First published in 197 I.)

Horsley, G. H. R. (I992) 'The inscriptions of Ephesos and the New Testament', Novum Testamentum 34: 105-68.

Hübner, S. (2003) 'Spiegel und soziale Gestaltungskraft alltäglicher Lebenswelt: der Kult des Men in Lydien und Phrygien', in Religion und Region: Götter und Kulte aus dem östlichen Mittelmeerraum, ed. E. Schwertheim and E. Winter. Bonn: 179-200.

Hume, D. (1956) The Natural History of Religion, ed. H. E. Root. Stanford, Calif. Hurtado, L. W. (2003) One God, One Lord: Early Christian devotion and ancient Jewish monotheism, and edn. London.

Jaeger, W. (1934) Paideia: Die Formung des griechischen Menschen. Leipzig and Berlin.

Janko, R. (2002-3) 'God, science and Socrates', BICS 46: I-I8.

Jarry, J. (1988) 'Datierungsprobleme in Nordsyrien', Tyche 3: I29-34.

Johnston, S. I. (1992) 'Riders in the sky: cavalier gods and theurgic salvation in the second century AD', CP 87: 303-2I.

Jones, C. P. (2005) 'Ten dedications "to the gods and goddesses" and the Antonine plague', $J R A$ i8: 293-30I.

(2006) 'Cosa and the Antonine plague', JRA i9: 368-9. 
Jordan, D. R. (2004) 'Magia nilotica sulle rive del Tevere', Mediterraneo Antico 7: 693-710.

Kahlos, M. (2002) Vettius Agorius Praetextatus: A senatorial life in between (Acta Instituti Romani Finlandiae 26). Rome.

Kaizer, T. (2006) 'In search of oriental cults', Historia 55: 26-47.

Kayser, F. (1994) Recueil des inscriptions grecques et latines (non funéraires) d'Alexandrie impériale (Ier-IIIe s. apr. J.-C.). Cairo.

Keel, O. (ed.) (1980) Monotheismus im Alten Israel und seiner Umwelt. Fribourg.

Kelly, J. N. D. (1972) Early Christian Creeds, 3rd edn. Harlow.

Kenney, J. P. (1986) 'Monotheistic and polytheistic elements in classical Mediterranean spirituality, in Classical Mediterranean Spirituality: Egyptian, Greek, Roman, ed. A. H. Armstrong. New York: 269-92.

(I99I) Mystical Monotheism: A study in ancient Platonic theology. London.

King, C. (2003) 'The organization of Roman religious beliefs', Classical Antiquity 22: 275-3I2.

Kirk, G., Raven, J. and Schofield, M. (1983) The Presocratic Philosophers: A critical history with a selection of texts. Cambridge.

Knibbe, D. (2002) 'Private evergetism in the service of the city-goddess: the most wealthy Ephesian family of the 2nd century CE supports Artemis in her struggle against the decline of her cult after the meteorological catastrophe of I86 CE', Mediterraneo Antico 5: 49-62.

Kobusch, Th. (1983) 'Das Christentum als die Religion der Wahrheit: Überlegungen zu Augustins Begriff des Kultus', Revue des Études Augustiniennes 29: 97-I28.

Koch, K. (1994) 'Monotheismus und Angelologie', in Ein Gott allein? JHWHVerehrung und biblischer Monotheismus im Kontext der israelitischen und altorientalischen Religionsgeschichte, ed. W. Dietrich and M. A. Klopfenstein. Fribourg: 565-8I.

(1999) 'Monotheismus als Sündenbock?', Theologische Zeitschrift I24: 873-84, reprinted in Assmann (2003), 22I-38.

Krämer, J. (2004) 'Lateinisch-griechisches Glossar: Celtis' Abschrift aus einem Papyruskodex', in Paramone: Editionen und Aufsätze von Mitgliedern des Heidelberger Instituts für Papyrologie zwischen 1982 und 2004, ed. J. M. S. Cowey and B. Kramer. Leipzig: 43-62.

Krebernik, M. and Van Oorschot, J. (eds.) (2002) Polytheismus und Monotheismus in den Religionen des Vorderen Orients (Alter Orient und Altes Testament 298). Münster.

Labarre, G. and Taşlialan, M. (2002) 'La dévotion au dieu Men: les reliefs rupestres de la Voie Sacrée', in Actes du ier Congrès International sur Antioche de Pisidie, ed. T. Drew-Bear and others. Lyon: 257-312.

Laks, A. (ed.) (2002) Traditions of Theology: Studies in Hellenistic theology, its background and aftermath. Leiden.

Lancellotti, M. G. (2000) The Naassenes: A gnostic identity among Judaism, Christianity, classical and ancient near eastern traditions. Leiden. 
Lane, E. N. (1975) Corpus Monumentorum Religionis Dei Menis II. The Coins and Gems. Leiden.

(1976) Corpus Monumentorum Religionis Dei Menis III. Interpretations and Testimonia. Leiden.

Lane Fox, R. (1986) Pagans and Christians in the Mediterranean World from the Second Century AD to the Conversion of Constantine. Harmondsworth.

Lang, B. (1993) 'Monotheismus', in Handbuch der religionswissenschaftlicher Grundbegriffe III, ed. H. Cancik and others. Stuttgart, Berlin and Cologne: I48-65.

Latte, K. (1960) Römische Religionsgeschichte. Munich.

Le Bris, A. (200I) La mort et les conceptions de l'au-delà en Grèce ancienne à travers les épigrammes funéraires: étude d'épigrammes d'Asie Mineure de l'époque hellénistique et romaine. Paris.

Le Dinahet, M.-T. (2002) 'Les inscriptions votives au dieu Men à Antioche: état des recherches', in Actes du Ier Congrès International sur Antioche de Pisidie, ed. T. Drew-Bear and others. Lyon: 2OI-I2.

Leclercq, H. (1924) 'Anges', in Dictionnaire d'Archéologie Chrétienne et de Liturgie I.2: $2080-216 \mathrm{I}$.

Lehmann, Y. (1980) 'Polythéisme et monothéisme chez Varron', REL 58: 25-9.

Lehmler, C. and Wörrle, M. (2006) 'Neue Inschriften aus Aizanoi Iv: Aizanitica Minora', Chiron 36: 45-III.

Levinskaya, I. (1996) The Book of Acts in its Diaspora Setting. Grand Rapids, Mich. Liebeschuetz, J. H. W. G. (1979) Continuity and Change in Roman Religion. Oxford.

(1999) 'The significance of the speech of Praetextatus', in Athanassiadi and Frede (I999), I85-205.

(200I) 'The influence of Judaism among non-Jews in the imperial period', Journal of Jewish Studies 52: 234-52.

Lieu, J. (1998) 'The forging of Christian identity and the Letter to Diognetus', Mediterranean Archaeology II: 7I-82, reprinted in Lieu (2002), I7I-89.

(2002) Neither Jew nor Greek. London and New York.

Livrea, E. (I998) 'Sull'iscrizione teosofica di Enonda', ZPE I22: 90-6.

Lona, H. E. (2005) Die 'wahre Lehre' des Celsus, übersetzt und erklärt (Kommentar zu den frühchristlichen Apologeten. Erg.-Bd. I). Freiburg etc.

Luhmann, N. (2000) Die Religion der Gesellschaft. Frankfurt.

Maas, M. (2000) Readings in Late Antiquity: A sourcebook. London and New York.

MacDonald, N. (2004) 'The origin of "monotheism", in Early Jewish and Christian Monotheism, ed. L. T. Stuckenbruck and W. E. S. North. London: 204-I4.

MacGregor, G. (1968) Introduction to Religious Philosophy. London and Melbourne.

MacMullen, R. (1977) Christianising the Roman Empire. New Haven.

(198I) Paganism in the Roman Empire. New Haven and London.

Malaise, M. (2005) Pour une terminologie et une analyse des cultes isiaques. Brussels.

Malay, H. (1994) Greek and Latin Inscriptions in the Manisa Museum. (Ergänzungsbände zu den TAM 19). Vienna.

(2003) 'A praise on Men Artemidorou Axiottenos', EA 36: I3-I8.

(2004) 'A dedicatory statuette of a mother goddess', $E A$ 37: 18I-2.

(2005) 'ФI $\triangle A N \Pi E \wedge O I$ in Phrygia and Lydia', EA 38: 42-3. 
Malouf, A. (1992) Préface to De la Divination/Cicéron, ed. G. Freyburger and J. Scheid. Paris.

Manemann, J. (ed.) (2002) Monotheismus (Jahrbuch Politische Theologie 4). Münster, Hamburg and London.

Manns, F. (1977) 'Nouvelles traces des cultes de Neotera, Sérapis et Poséidon en Palestine', Liber Annus 27: 229-38.

Marek, C. (1993) Stadt, Ära und Territorium in Pontus-Bithynia und Nord-Galatia. Tübingen.

(2000) 'Der höchste, beste, größte, allmächtige Gott: Inschriften aus Nordkleinasien', $E A$ 32: 129-46.

Markschies, C. (200I) 'Heis Theos? Religionsgeschichte und Christentum bei Erik Peterson', in Vom Ende der Zeit: Geschichtstheologie und Eschatologie bei Erik Peterson (Symposium Mainz. Religion-Geschichte-Gesellschaft Band I6), ed. B. Nichtweis. Münster: 38-74.

(2002) 'Heis Theos - Ein Gott ? Der Monotheismus und das antike Christentum', in Polytheismus und Monotheismus in den Religionen des Vorderen Orients, ed. M. Krebernik and J. van Oorschot (AOAT 298). Münster: 20934 .

(2006) 'Ist Monotheismus gefährlich? Einige Beobachtungen zu einer aktuellen

Debatte aus der Spätantike', Berichte und Abhandlungen der BerlinBrandenburgischen Akademie der Wissenschaften IO: II-24.

(forthcoming) Revised new edition of Peterson (1926). Würzburg.

Markus, R. (1990) The End of Ancient Christianity. Cambridge.

Marquard, O. (ed.) (200oa) Abschied vom Prinzipiellen: Philosophische Studien. Stuttgart.

(2000b) 'Lob des Polytheismus', in Marquard (2000a): 9I-II6. (First published in $198 \mathrm{I}$.)

Mastandrea, P. (1979) Un neoplatonico latino: Cornelio Labeone. Leiden.

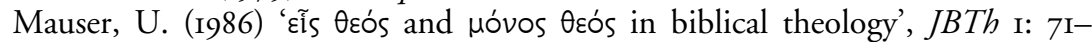
87.

Mawson, T. J. (2005) Belief in God: An introduction to the philosophy of religion. Oxford.

Meier, M. (2003) Das andere Zeitalter Justinians: Kontingenzerfahrung und Kontingenzbewältigung im 6. Jahrhundert n. Chr. Göttingen. (2004) Justinian: Herrschaft, Reich und Religion. Munich.

Merkelbach, R. (200I) Isis regina - Zeus Sarapis: Die griechisch-ägyptische Religion nach den Quellen dargestellt. Munich and Leipzig.

Michel, S. (200I) Die magischen Gemmen im Britischen Museum. London.

Mikalson, J. D. (1998) Religion in Hellenistic Athens. Berkeley.

Mitchell, S. (1993), Anatolia: Land, men, and gods in Asia Minor II. The rise of the Church. Oxford.

(1998) 'Wer waren die Gottesfürchtigen?', Chiron 28: 55-64.

(I999) 'The cult of Theos Hypsistos between pagans, Jews, and Christians', in Athanassiadi and Frede (I999), 8I-I48.

(2003a) 'Inscriptions from Melli (Kocaaliler) in Pisidia', AS 53: 139-59. 
(2003b) 'Rom und das Judentum in der frühen Kaiserzeit: Überlegungen zu den Grenzen zwischen Heiden, Juden und Christen', in Leitbild Wissenschaft? (Altertumswissenschaftliches Kolloquium 8), ed. J. Dummer and M. Vielberg. Stuttgart: $149-72$.

(2005) 'An Apostle to Ankara from the New Jerusalem: Montanists and Jews in Late Roman Asia Minor', SCI 24: 207-23.

(2008) 'La comunicazione di ideologie religiose nell'impero romano', in $\mathrm{La}$ comunicazione nella storia antica: fantasie e realtà, ed. M. Angeli Bertinelli. Rome: 57-69.

(forthcoming) 'Ein Gott im Himmel: zur Problematik des heidnischen monotheismus in der Kaiserzeit und der Spätantike', ZAC.

Mitchell, S. and Van Nuffelen, P. (eds.) (2009) Monotheism between Pagans and Christians in Late Antiquity. Leuven.

Miura-Stange, A. (1926) Celsus und Origenes: Das Gemeinsame ihrer Weltanschauung nach den acht Büchern des Origenes gegen Celsus. Eine Studie zur Religionsund Geistesgeschichte des 2. und 3. Jahrhunderts. Gießen.

Moberly, R. W. L. (2004) 'How appropriate is "monotheism" as a category for Biblical interpretation', in Early Jewish and Christian Monotheism, ed. L. T. Stuckenbruck and W. E. S. North. London: 216-34.

Moltmann, J. (2002) 'Kein Monotheismus gleicht dem anderen: Destruktion eines untauglichen Begriffs', Evangelische Theologie 62: II2-222.

Momigliano, A. D. (1984) 'Religion in Athens, Rome and Jerusalem in the first century вс', Annali della Scuola Normale di Pisa 3rd ser., I4: 873-92, reprinted in Momigliano (1987), 74-9I [= Ottavo contributo, 279-96].

(1986) 'The disadvantages of monotheism for a universal state', CPh 81: $285-$ 97.

(1987) On Pagans, Jews and Christians. Middletown, Conn.

Moreschini, C. (1983) 'Monoteismo cristiano e monoteismo platonico nella cultura latina dell'età imperiale', in Platonismus und Christentum: Festschrift für Heinrich Dörrie (JbAC Erg. Band Io), ed. H.-D. Blume and F. Mann. Münster: I33-6I.

Most, G. W. (2003) 'Philosophy and religion', in The Cambridge Companion to Greek and Roman Philosophy, ed. D. Sedley. Cambridge: 300-22.

Mrozek, S. (197I) 'Primus omnium sur les inscriptions des municipes italiens', Epigraphica 33: 60-9.

Mühlenkamp, C. (2008) 'Nicht wie die Heiden': Studien zur Grenze zwischen christlicher Gemeinde und paganer Gesellschaft in vorkonstantinischer Zeit (JbAC Erg.-Bd. Kleine Reihe 3). Münster.

Müller, B. (I9I3) Mér $\propto s$ $\theta$ cós (Diss. Philologicae Halenses Xxi). Halle.

Müller, F. M. (1882) Lectures on the Origin and Growth of Religion, as Illustrated by the Religions of India. London.

Niebuhr, H. R. (1943) Radical Monotheism and Western Culture. New York.

Nilsson, M. (1950) Geschichte der griechischen Religion II. Die hellenistische und römische Zeit. Munich.

(1963) 'The High God and the mediator', HThR 56: IOI-20. 
Nock, A. D. (1928) 'Oracles théologiques', REA 30: 280-90, reprinted in Nock (1972), 160-8.

(1933) Conversion: The old and the new in religion from Alexander the Great to Augustine of Hippo. Oxford.

(1940) 'Orphism or popular philosophy?', HThR 33: 30I-I5.

(1972) Essays on Religion and the Ancient World, ed. Z. Stewart. Oxford.

Nollé, J. (1993) 'Die feindlichen Schwestern: Betrachtungen zur Rivalität der pamphylischen Städte', in Die epigraphische und altertumskundliche Erforschung Kleinasiens: Hundert Jahre Kleinasiatische Kommission der Österreichischen Akademie der Wissenschaften. Akten des Symposiums vom 23. bis 25. Oktober 1990, ed. G. Dobesch and G. Rehrenböck. Vienna: 297-317.

(1996) Side im Altertum: Geschichte und Zeugnisse I. Bonn.

North, J. (1979) 'Religious toleration in republican Rome', PCPS 25: 85-IO3.

(1992) 'The development of religious pluralism', in The Jews among Pagans and Christians, ed. J. Lieu, J. North and T. Rajak. London: 174-93.

(2003) 'Réflexions autour des communautés religieuses du monde grécoromain', in Les communautés religieuses dans le monde gréco-romain: essais de définition, ed. N. Belayche and S. C. Mimouni. Turnhout: 337-47.

(2005) 'Pagans, polytheists and the pendulum', in The Spread of Christianity in the First Four Centuries: Studies in explanation, ed. W. V. Harris. Leiden: I3I-4.

(2007) 'Arnobius on sacrifice', in Wolf Liebeschuetz Reflected, ed. J. Drinkwater and B. Salway. London: 27-36.

O'Daly, G. (1999) Augustine's City of God: A reader's guide. Oxford.

Osborne, T. P. (2003) 'Le conflit des cultes dans l'Apocalypse de Jean', in Dieux, fêtes, sacré dans la Grèce et la Rome antiques, ed. A. Motte and C. M. Ternes. Turnhout: 236-54.

Palmer G. (ed.) (2007) Fragen nach dem einen Gott: Die Monotheismusdebatte im Kontext (Religion und Aufklärung I4). Tübingen.

Pandermalis, D. (2005) 'Zeùs 'Y Makedonia kai Thrake (Thessalonica) I7 (2003, published 2005): 417-28.

Parker, R. (1998) 'Pleasing thighs: reciprocity in Greek religion', Reciprocity in Ancient Greece, ed. C. Gill, N. Postlethwaite and R. Seaford. Oxford: IO525 .

(2005) Polytheism and Society at Athens. Oxford.

Peek, W. (1930) Der Isishymnus von Andros. Berlin.

Peres, I. (2003) Griechische Grabinschriften und neutestamentliche Eschatologie. Tübingen.

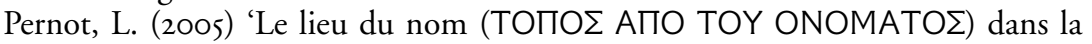
rhétorique religieuse des Grecs', in Belayche and others (2005), 29-39.

Peterson, E. (1926) EI $\Theta \mathrm{EO} \Sigma$ : Epigraphische, formgeschichtliche und religionsgeschichtliche Untersuchungen (Forschungen zur Religion und Literatur des Alten und Neuen Testaments 24). Göttingen.

(195I) 'Das Problem des Nationalismus im alten Christentum', Theologische Zeitschrift 7: 8I-9I. 
Petrovic, I. and Petrovic, A. (2006) “"Look who is talking now!”: speaker and communication in Greek metrical sacred regulations', in Rituals and Communication in the Graeco-Roman World, ed. E. Stavrianopoulou. Liège: I5I-79.

Petzl, G. (1994) Die Beichtinschriften Westkleinasiens (Epigraphica Anatolica 22). Bonn.

(1998) Die Beichtinschriften im römischen Kleinasien und der Fromme und Gerechte Gott (Nordrhein-Westfälische Akademie der Wissenschaften, Vorträge G 355). Opladen.

(2003) 'Zum religiösen Leben im westlichen Kleinasien: Einflüsse und Wechselwirkungen', in Religion und Region: Götter und Kulte aus dem östlichen Mittelmeerraum, eds. E. Schwertheim and E. Winter. Bonn: 93-IO2.

Philipp, H. (1986) Mira et magica: Gemmen im Ägyptischen Museum der Staatlichen Museen Preussischer Kulturbesitz, Berlin-Charlottenburg. Mayence.

Phillips, C. R. (1986) 'The sociology of religious knowledge', in $A N R W$ II.I6.3: 2677-773.

Pichler, K. (1980) Streit um das Christentum: Der Angriff des Celsus und die Antwort des Origenes. Frankfurt a.M. and Berne.

Pilhofer, P. (1995) Philippi I. Die erste christliche Gemeinde Europas. Tübingen.

Pleket, H. W. (198I) 'Religious history as the history of mentality: the "believer" as servant of the deity in the Greek world', in Faith, Hope and Worship: Aspects of religious mentality in the ancient world, ed. H. S. Versnel. Leiden: 152-92.

Porter, B. N. (ed.) (2000) One God or Many? Concepts of divinity in the ancient world. Chebeague.

Posamentir, R. and Wörrle, M. (2006) 'Der Zeustempel von Aizanoi: ein Großbau flavischer Zeit', $M D A I(I)$ 56: 227-46.

Potter, D. S. (1990) Prophecy and History in the Crisis of the Roman Empire. Oxford. Preisendanz, K. (1928) Papyri Graecae Magicae. Leipzig and Berlin.

Price, S. R. F. (1984) Rituals and Power: The Roman imperial cult in Asia Minor. Cambridge.

(1999) Religions of the Ancient Greeks (Key Themes in Ancient History). Cambridge.

(2003) 'Homogénéité et diversité dans les religions à Rome', $A R G$ 5: I80-97.

Queyrel, F. (1992) 'Les acclamations peintes du xyste', in Delphes: centenaire de la grande fouille réalisée par l'EFA (I892-I903) (Travaux du CERPOGA I2), ed. J.-F. Bommelaer. Strasbourg: 333-48.

(200I) 'Inscriptions et scènes figurées peintes sur le mur du fond du xyste de Delphes', $B C H$ I25: 333-87.

Ramnoux, C. (1984) 'Sur un monothéisme grec', $R P h L$ 82: 175-98.

Ramsay, W. M. (I883) 'Unedited inscriptions of Asia Minor', BCH 7: 297-327.

(1889) 'Artemis-Leto and Apollo Lairbenos', JHS Io: 216-30.

Rappaport, R. (I999) Ritual and Religion in the Making of Humanity. Cambridge.

Ratzinger, J. (I97I) Die Einheit der Nationen: Eine Vision der Kirchenväter. Salzburg and Munich.

Richter, G. M. A. (1956) Catalogue of Engraved Gems: Greek, Etruscan and Roman, Metropolitan Museum of Art, New York. Rome. 
Ricl, M. (I99I-2) 'Hosios kai Dikaios', EA I8: I-70 and 19: 7I-IO3.

Ritti, T. (2002-3) 'Antonino Pio, "padrone della terra e del mare": una nuova iscrizione onoraria da Hierapolis di Frigia', Annali di archeologia e di storia antica 9/IO: 27I-82.

Rives, J. (1999) 'The decree of Decius and the religion of Empire', JRS 89: 135-54. (2007) Religion in the Roman Empire. Maldon, Mass., Oxford and Carlton.

Robert, J. and Robert, L. (1948) Hellenica VI. Inscriptions grecques de Lydie. Paris.

Robert, L. (1937) Études anatoliennes. Paris.

(1938) Etudes épigraphiques et philologiques. Paris.

(I955) Hellenica X. Paris.

(1958) 'Reliefs et cultes votifs d'Anatolie', Anatolia 3: I03-36. (= Robert, OMS I: 402-35).

(1964) Nouvelles inscriptions de Sardes. Paris.

(1968) 'Trois oracles de la Théosophie et un prophète d'Apollon', CRAI I968: 568-99 (= Robert, OMS v: 584-615).

(1969) 'Les épigrammes satiriques de Lucilius sur les athlètes: parodies et réalités', in L'épigramme grecque (Entretiens Fondation Hardt I4). GenevaVandoeuvres: I79-295 (= Robert, OMS vi: 317-43I; Choix d'écrits, ed. D. Rousset, Paris 2007: 175-246).

(197I) 'Un oracle gravé à Oinoanda', $C R A I$ I97I: 597-6r9 (= Robert, OMS v, 6I7-39).

(1983) 'Reliefs d'Asie Mineure', BCH I07: 583 (= Documents d'Asie Mineure, Paris I987: 427).

Roberts, C., Skeat, T. C. and Nock, A. D. (1936) 'The guild of Zeus Hypsistos', HThR 29: 39-87, reprinted in Nock (I972), 4I4-43.

Rose, H. J. and others (1954) La notion du divin depuis Homère jusqu'à Platon (Fondation Hardt, Entretiens sur l'Antiquité classique I). Geneva-Vandoeuvres.

Rothaus, R. M. (1996) 'Christianization and de-paganization: the late antique creation of a conceptual frontier', in Shifting Frontiers in Late Antiquity, ed. R. Mathisen and H. J. Sivan. Aldershot: 299-308.

Roueché, C. (1984) 'Acclamations in the later Roman empire: new evidence from Aphrodisias', JRS 74: I8I-99.

(1989a) Aphrodisias in Late Antiquity. London.

(1989b) 'Floreat Perge', in Images of Authority: Papers presented to Joyce Reynolds on the occasion of her seventieth birthday, ed. M. M. Mackenzie and C. Roueché. Cambridge: 206-28.

(1995) 'Aurarii in the auditoria', ZPE I05: 37-50.

Rougemont, G. (2004) 'Dédicace d'Héliodotos à Hestia pour le salut d'Euthydème et de Démétrios', Journal des Savants 2004: 333-7.

Roussel, P. (I93I) 'Le miracle de Zeus Panamaros', $B C H$ 55: 70-II6.

Rudhardt, J. (I966) 'Considérations sur le polythéisme', Revue de Théologie et de Philologie 99: 353-64.

Rüpke, J. (200I) Die Religion der Römer. Munich.

(2004) 'Acta aut agenda: relations of script and performance', in Rituals in Ink, ed. A. Barchiesi. Stuttgart: $23-44$. 
(2005) Fasti sacerdotum: Die Mitglieder der Priesterschaften und das sakrale Funktionspersonal römischer, griechischer, orientalischer und judisch-christlicher Kulte in der Stadt Rom von 300 v. Chr. bis 499 n. Chr. Stuttgart.

(2006) 'Literarische Darstellungen römischer Religion in christlicher Apologetik: Universal- und Lokalreligion bei Tertullian und Minucius Felix', in Texte als Medium und Reflexion von Religion im römischen Reich, ed. D. E. von der Osten, J. Rüpke and K. Waldner. Stuttgart: 209-23.

Rutgers, L. (1995) The Jews in Late Ancient Rome: Evidence of cultural interaction in the Roman diaspora. Leiden.

(1998) The Hidden Heritage of Diaspora Judaism. Leuven.

Rutherford, I. (2000) 'The reader's voice in a horoscope from Abydos', $Z P E_{\mathrm{I}} 30$ : I49-50.

Şahin, M. Ç. (2002) 'New inscriptions from Lagina, Stratonikeia and Panamara', EA 34: I-2I.

Sanzi, E. (2002) 'Magi e culti orientali', in Gemme gnostiche e cultura ellenistica, ed. A. Mastrocinque. Bologna: 207-24.

Scheid, J. (I988) 'L'impossible polythéisme: les raisons d'un vide dans l'histoire de la religion romaine', in L'impensable polythéisme, ed. F. Schmidt. Paris.

(1998a) Commentarii Fratrum Arvalium qui supersunt: les copies épigraphiques des protocoles annuels de la confrérie arvale. Rome.

(1998b) La religion des romains. Paris.

(I999) 'Hiérarchie et structure dans le polythéisme romain: façons romaines de penser l'action', $A R G$ I: I84-203.

(2005) Quand croire, c'est faire: les rites sacrificiels des Romains. Paris.

(ed.) (2007) Rites et croyances dans le monde romain (Entretiens Fondation Hardt 53). Geneva-Vandoeuvres.

Schelling, F. W. J. (1985) Philosophie der Mythologie. Frankfurt. (First published in I842.)

Schleiermacher, F. (1828) Der christliche Glaube. Berlin.

(1960) Der christliche Glaube nach den Grundsätzen der evangelischen Kirche im Zusammenhang dargestellt: Auf Grund der 2. Auflage und kritischen Prüfung des Textes neu herausgegeben von Martin Redeker. Berlin.

Schmidt, F. (ed.) (1988) L'impensable polythéisme. Paris.

Schneider, A. M. (1949/5I) 'Römische und byzantinische Bauten auf dem Garizim', ZDPV 68: 2II-34, reprinted in Schneider (1998), 187-204.

(1998) Reticulum: Ausgewählte Aufsätze und Katalog seiner Sammlungen. Münster.

Schröder, H. O. (1986) Heilige Berichte. Einleitung, deutsche Übersetzung und Kommentar. Heidelberg.

Schürer, E. (I897) 'Die Juden im bosporanischen Reich und die Genossenschaft

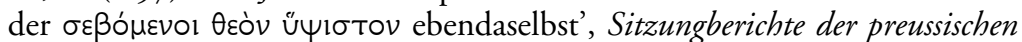
Akademie der Wissenschaften zu Berlin 1897: 200-25.

(varying dates) The History of the Jewish People in the Age of Jesus Christ, revised edition by G. Vermes, F. Millar and others, I-III.2. Edinburgh. 
Schwabe, M. (195I) 'A Jewish inscription from Ed-Dumèr near Damsacus', $P A A J R$ 20: $265-77$.

Schwöbel, C. (I994) 'Monotheismus IV. Systematisch-Theologisch', in TRE 23: 256-26.

Sérandour, A. (2004) 'De l'apparition d'un monothéisme en Israël', Diogène 205: 28-5I.

Sfameni Gasparro, G. (1986) Soteriology and Mystic Aspects in the Cult of Cybele and Attis. Leiden.

(1996) 'Alessandro di Abonutico, lo "pseudo-profeta" ovvero come construirsi un'identità religiosa I. Il profeta, "eroe" e "uomo divino"', Studi e Materiali di Storia delle Religioni 62: 565-90.

(1999) 'Alessandro di Abonutico, lo "pseudo-profeta" ovvero come construirsi un'identità religiosa II. L'oracolo e i misteri', in Les syncrétismes religieux dans le monde méditerranéen antique: Actes du colloque international en l'honneur de Franz Cumont, ed. C. Bonnet and A. Motte. Brussels and Rome: 275-305.

(2003) 'Monoteismo pagano nella Tarda Antichità: una questione di tipologia storico-religiosa', Annali di Scienze Religiose 8: 97-I27.

(2006) 'Strategie di salvezza nel mondo hellenistico-romano: per una tassonomia storico-religiosa', in Pagani e Cristiani alla ricerca della salvezza (secoli IIII): XXXIV Incontro di studiosi dell'antichità cristiana, Roma, 5-7 maggio 2005 (Studia Ephemeridis Augustinianum 96). Rome: 2I-53.

Simon, M. (1973) 'Early Christianity and pagan thought: confluences and conflicts', Religious Studies 9: 385-99.

Skarsaune, O. (1997) 'Is Christianity monotheistic? Patristic perspectives on a Jewish/Christian debate', Studia Patristica 29: 340-63.

Smith, J. Z. (1990) Drudgery Divine: On the comparison of early Christianities and the religions of late antiquity. London.

(2002) 'Great Scott! Thought and action one more time', in Magic and Ritual in the Ancient World, ed. P. Mirecki and M. Meyer. Leiden: 73-9I.

(2004) Relating Religion: Essays in the study of religion. Chicago and London.

Speigl, J. (1970) Der römische Staat und die Christen: Staat und Kirche von Domitian bis Commodus. Amsterdam.

Spieckermann, H. and Kratz, R. G. (eds.) (2006) Götterbilder - Gottesbilder Weltbilder: Polytheismus und Monotheismus in der Welt der Antike I/2 (Forschungen zum Alten Testament 2. Reihe 17/8). Tübingen.

Spier, J. (1992) Ancient Gems and Finger Rings: Catalogue of the collections of the J. Paul Getty Museum. Malibu, Calif.

Stark, R. (1996) The Rise of Christianity: A sociologist reconsiders history. Princeton, NJ.

(200I) One True God: Historical consequences of monotheism. Princeton.

Stark, R. and Bainbridge, W. S. (1987) A Theory of Religion. New Brunswick, NJ.

Stehle, E. (2004) 'Choral prayer in Greek tragedy: euphemia or aischrologia?', in Music and the Muses: The culture of mousike in the classical Athenian city, ed. P. Murray and P. Wilson. Oxford: I2I-55. 
(2005) 'Prayer and curse in Aeschylus' Seven Against Thebes', CP ıо: IOI-22.

Stein, M. (200I) 'Die Verehrung des Theos Hypsistos: ein allumfassender paganjüdischer Synkretismus?', EA 33: II9-26.

Stemberger, G. (1987) Juden und Christen im Heilige Land: Palästina unter Konstantin und Theodosius. Munich.

Stolz, F. (1996) Einführung in den biblischen Monotheismus. Darmstadt.

Stroumsa, G. G. (2005) La fin du sacrifice: les mutations religieuses de l'Antiquité tardive. Paris.

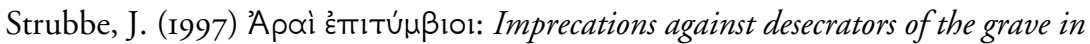
the Greek epitaphs of Asia Minor. A catalogue. Bonn.

Suarez de la Torre, E. (2003) 'Apollo, teologo cristiano', Annali di Scienze Religiose 8: $129-52$.

Taeuber, H. (2003) 'Graffiti als Hilfsmittel zur Datierung der Wandmalereien in Hanghaus 2', in Das Hanghaus 2 von Ephesos: Studien zu Baugeschichte und Chronologie, ed. F. Krinzinger. Vienna: 93-9.

Teixidor, J. (I977) The Pagan God: Pagan religion in the Graeco-Roman Near East. Princeton.

Theissen, G. (1985) Biblical Faith: An evolutionary approach. Philadelphia.

Thom, J. C. (2005) Cleanthes' Hymn to Zeus. Tübingen.

Thonemann, P. (2007) 'Estates and the land in late Roman Asia Minor', Chiron 37: $435-78$.

Tod, M. N. (I949) 'Greek record-keeping and record-breaking', CQ 43: I05-I2.

Totti, M. (1985) Ausgewählte Texte der Isis- und Sarapis-Religion. Hildesheim, Zurich and New York.

Trebilco, P. (2002) 'The Christian and Jewish Eumeneia formula', Mediterraneo Antico 5: 63-97.

Tremlin, T. (2006) Minds and Gods: The cognitive foundations of religion. Oxford.

Trombley, F. R. (1993-4) Hellenic Religion and Christianisation (Religions in the Graeco-Roman World II5), 2 vols. Leiden and New York.

Turcan, R. (1989) Les cultes orientaux dans le monde romain. Paris.

(1998) Rome et ses dieux. Paris.

(1999) 'Conclusions', in Les syncrétismes religieux dans le monde méditerranéen antique: Actes du Colloque F. Cumont, septembre 1997, ed. C. Bonnet and A. Motte. Rome: 385-400.

(2000a) Mitra et le Mithracisme, 2nd edn. Paris.

(200ob) The Gods of Ancient Rome (English translation of Turcan 1998). Edinburgh.

Tybout, R. A. (2003) 'Naar een andere wereld: verkenningen van het Griekse grafepigram op steen', Lampas 36: 329-77.

Ustinova, Y. (I99I) 'The thiasoi of Theos Hypsistos in Tanais', History of Religions 3I: $150-80$.

(1999) The Supreme Gods of the Bosporan Kingdom: Celestial Aphrodite and the Most High God (Religions in the Graeco-Roman World I35). Leiden, Boston and Köln. 
Van den Bosch, L. P. (2002) Friedrich Max Müller: A life devoted to the humanities. Leiden.

Van den Broek, R. and others (eds.) (1988) Knowledge of God in the Graeco-Roman World. Leiden.

van der Horst, P. W. (I992) 'A new altar of a god-fearer?', JJS 43: 32-7, reprinted in van der Horst (1998), 65-70.

(1998) Hellenism - Judaism - Christianity. Leuven.

Van Nuffelen, P. (forthcoming a) 'Varro's Antiquitates rerum divinarum: Roman religion as an image of truth', Classical Philology.

(forthcoming b) Philosophical Readings of Religion in the Post-Hellenistic Period.

Van Selms, A. (1973) 'Temporary henotheism', in Symbolae biblicae et Mesopotamicae Francisco Mario Theodoro de Liagre Böhl dedicatae, ed. M. A. Beek and others. Leiden: $34 \mathrm{I}-8$.

Vanderlip, V. F. (1972) The Four Greek Hymns of Isidorus and the Cult of Isis. Toronto.

Vermaseren, M. J. and Van Essen, C. C. (1965) The Excavations in the Mithraeum of the Church of Santa Prisca in Rome. Leiden.

Vernant, J-P. (1985) Mythe et pensée chez les Grecs, 2nd edn. Paris.

Versnel, H. S. (ed.) (1981a) Faith, Hope and Worship: Aspects of religious mentality in the ancient world. Leiden.

(I98Ib) 'Religious mentality in ancient prayer', in Versnel (I98Ia) I-64.

(1990) Inconsistencies in Greek and Roman Religion I. Ter unus. Isis, Dionysos, Hermes: Three studies in henotheism. Leiden.

(2000) 'Thrice one: three Greek experiments in oneness', in One God or Many? Concepts of divinity in the ancient world, ed. B. N. Porter. Chebeague: 79-I63.

Veyne, P. (I986) 'Une évolution du paganisme gréco-romain: injustice ou piété des dieux, leurs ordres et "oracles"', Latomus 45: 259-83, reprinted in Veyne (I99I), 28I-3IO.

(1990) 'Images de divinités tenant une phiale ou patère: la libation comme "rite de passage" et non pas offrande', Metis 5: 17-28.

(I99I) La société romaine. Paris.

(2005) L'Empire gréco-romain. Paris.

Victor, U. (1997) Lukian von Samosata, Alexander oder Der Lügenprophet. Eingeleitet, herausgegeben, übersetzt und erklärt. Leiden, New York and Cologne.

Vinzent, M. (1998) 'Das "heidnische” Ägypten im 5. Jahrhundert', in Heiden und Christen im 5. Jahrhundert, ed. J. van Oort and D. Wyrwa. Leuven: 3265 .

Waldner, K. (2007) 'Les martyrs comme prophètes: divination et martyre dans le discours chrétien des Ier et IIe siècles', RHR 224: 193-209.

Wallraff, M. (2002) Christus verus sol. Münster.

(2003) 'Pagan monotheism in late antiquity: remarks on a recent publication', Mediterraneo Antico 6: 53I-6.

Wander, B. (1998) Gottesfürchtige und Sympathisanten. Tübingen.

Warde Fowler, W. (I9I2) The Religious Experience of the Roman People. London. 
Weichlein, S. (2003) Review of Jürgen Manemann (ed.), Monotheismus (Münster 2002), Humanities and Social Sciences 2003, available at: http://www.h-net. org/reviews/showrev.php?id=176I6.

Welles, C. B. (1938) 'The inscriptions', in Gerasa, ed. C. H. Kraeling. New Haven: $355-494$.

West, M. (I999) 'Towards monotheism', in Athanassiadi and Frede (I999), 2I-40.

Whitehouse, H. (2004) Modes of Religiosity: A cognitive theory of religious transmission. Walnut Creek, Calif.

Wiemer, H.-U. (2004) 'Akklamationen im spätrömischen Reich. Zur Typologie und Funktion eines Kommunikationrituals', Archiv für Kulturgeschichte 86: $27-73$.

Wifstrand, A. (1942) 'Die wahre Lehre des Celsus', Bulletin de la Société Royale des Lettres de Lund I94I-2: 39I-43I (in separate pagination: I-4I).

Williams, B. (1963) 'Hume on religion', in David Hume: A Symposium, ed. D. F. Pears. London: 77-88, reprinted in Williams (2006), 267-73.

(2006) The Sense of the Past, ed. M. Burnyeat. Princeton and Oxford.

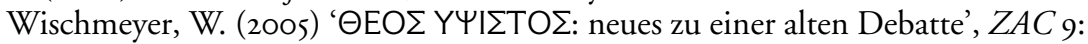
I49-68.

Wissowa, G. (I912) Religion und Kultus der Römer, 2nd edn. Munich.

Zeller, E. (I862) Die Entwicklung des Monotheismus bei den Griechen. Stuttgart.

(I875) Vorträge und Abhandlungen geschichtlichen Inhalts I, 2nd edn. Leipzig. 